\title{
Consideration of climatic factors in the operating mode of hydraulic facilities in the Amudarya river basin
}

\author{
Farrukh Kattakulov ${ }^{1}$, Fotima Artikbekova ${ }^{1 *}$, Zafar Gafurov $^{2}$, Gulnora Jumabaeva ${ }^{1}$ \\ Furqat Musulmanov ${ }^{3}$ \\ ${ }^{1}$ Tashkent institute of irrigation and agricultural mechanization engineers, Tashkent, Uzbekistan \\ ${ }^{2}$ International Water Management Institute, Tashkent, Uzbekistan \\ ${ }^{3}$ Bukhara Branch of the Tashkent Institute of Irrigation and Agricultural Mechanization Engineers, \\ Bukhara, Uzbekistan
}

\begin{abstract}
This research is devoted to the analysis of the dynamics of climate change in the Amu Darya river basin using the global climate model and observational data. And also, the purpose of the study is to scale down and correct the offset of the GCF and adaptation to the Amu Darya river basin and assess the dynamic climate change and its future predictions of the impact on the hydraulic structures of the Amu Darya river basin. The offset correction was carried out on the basis of data from open sources from the archives of the world meteorological organizations and the analysis performed for the next 100 years. The article analyzes the results of the regions affected by the climate [1] from the point of view of the reduction of water resources, the disappearance of glaciers, an increase in temperature, and a decrease in precipitation. An increase in temperature leads to a steady decrease in the area of large glaciers, while small glaciers gradually completely disappear and a change in the ratio of solid and liquid precipitation alternately, which leads to a reduction in snow cover and is also accompanied by degradation and melting of snow cover permafrost in high mountain areas. For future projections of glacier area and melt water release, glacier volume is required. Climate change affects the hydrological regime of the river; this process worsens the operational regime of hydraulic structures in the Amu Darya basin. Such changes in glaciation, snow cover, and permafrost negatively affect the change in river flow and its distribution and the ecological assessment of the quality of the environment. Therefore, the study of changes in climatic conditions in the region and the development of climate change scenarios for the XXI century is carried out following the recommendations of the IPCC using the necessary programs.
\end{abstract}

\section{Introduction}

In modern conditions and in the future, the shortage of water resources in Central Asia is seen as one of the main limiting factors for developing the countries of the region. The

\footnotetext{
*Corresponding author: vohidov.oybek@bk.ru
} 
expected increase in water consumption here leads to competition for water at the regional and local levels between irrigation and energy, other sectors of the economy. Intensive climate warming is noted throughout Central Asia and the prospective assessment of the region's water resources, taking into account climate change, shows that none of the considered climate scenarios reflecting warming involves an increase in the available water resources [1-7]. The calculations obtained indicate that by 2050 the volume of river flow in the Amu Darya basin will decrease by $10-15 \%$ and in the Syr Darya by $6-10 \%$.

In addition, the glaciers of Tajikistan play an important role in the formation of the Amu Darya rivers, which are considered the largest waterways. In this arid region, future impacts of climate change could directly impact glacier volumes, food sources, and river flows [812].

An increase in temperature leads to a steady decrease in the area of large glaciers, while small glaciers gradually completely disappear and a change in the ratio of solid and liquid precipitation alternately, which leads to a reduction in snow cover, and is also accompanied by degradation and melting of snow cover permafrost in high mountain regions [13, 17, 18 ]. For future projections of glacier area and melt water release, the volume of glaciers is required. Climate change affects the hydrological regime of the river; this process worsens the operational regime of hydraulic structures in the Amu Darya basin. Such changes in glaciation, snow cover, and permafrost negatively affect the change in river flow and its distribution and the ecological assessment of the quality of the environment. Therefore, the study of changes in climatic conditions in the region and the development of climate change scenarios for the 21 st century is carried out following the recommendations of the IPCC using the necessary programs [5].

The rapid development of agriculture and an increase in the need for irrigation of lands, characteristic of the hot climate of Central Asia, and an increase in water consumption by the population of the republic led to a sharp change in the regime of movement and nonstationary movement of the flow of water flow in rivers [14-20]. To provide agriculture with the required volume of water, the design and construction of many hydraulic structures and the reconstruction of existing facilities are required. All this contributes to a sharp change in water discharge in river beds, which leads to a change in the morphometry of the river bed.

\section{Methods}

Analysis of the results of field research, taking into account climatic factors on the operational regime of hydraulic structures in the Amu Darya basin, forecasting climate change using the necessary programs is the research method of this work.

\section{Results and Discussion}

Water for irrigated land in the Aral Sea Basin comes from two large rivers, the Amu Darya and the Syr Darya rivers, flowing from the producing countries to the downstream, reaching as far as the Aral Sea. This study aims to study climate change and future projections for the Amu Darya basin. The Amu Darya is the largest river in Central Asia, with a catchment area of $309,000 \mathrm{~km} 2$ and a length of $2540 \mathrm{~km}$ [3-7]. It is a transboundary river shared by Afghanistan, Kyrgyzstan, Tajikistan, Turkmenistan, and Uzbekistan.

The Amu Darya basin, the largest river basin in Central Asia in terms of a catchment area, covers an area of $1,326,000 \mathrm{~km}^{2}$, of which $1,017,835 \mathrm{~km}^{2}$ falls on the territory of the Commonwealth of Independent States (CIS) countries, which are hydrographically related to the large Amu Darya basin. The catchment boundaries of the basin are clearly identified 
within the mountainous region: in the south, they pass along the Hindu Kush ridge, in the east - along the Sarykol ridge, and in the north - along the Alay, Turkestan, and Nurata ridges [20-23]. A large area occupied by glaciers and snowfields determines the nature of the feeding of the largest rivers in the basin, most of which belong to the rivers of glaciersnow feeding (Amu Darya, Pyanj, Vakhsh, Zeravshan, and some others). Only the rivers that form the runoff in the western part of the basin, where the ridges are distinguished by lower heights, belong to the rivers of snow-glacial and partially snow-fed (Kafirnigan, Kyzylsu, Surkhandarya, Kashkadarya).

The mountainous part is represented by the highest ridges - Zaalaysky, them. Peter the Great, them. Academy of Sciences, Rushansky, and Vakhshsky, - a large area (10,000 km2) is occupied by glaciation zones, including the largest Fedchenko glacier feeding the river. Vakhsh. The plateaus lying at an altitude of 800-4000 $\mathrm{m}$ above sea level are cut by deep river valleys. Situated in the center of the vast Eurasian continent, remote from the seas and oceans, the basin's territory is characterized by a continental climate with an abundance of warm and sunny days. Most of it is occupied by huge flat areas of the Karakum and Kyzylkum desert sandy deserts, as well as semi-deserts characterized by great dryness. Annual precipitation is $220 \mathrm{~mm}$; in some places, it does not exceed $100 \mathrm{~mm}$ (delta of the Zeravshan River, lower reaches of the Amu Darya River). The average annual temperature ranges from +14 to $+17^{\circ} \mathrm{C}$, winter - from +1 to $+2{ }^{\circ} \mathrm{C}$, summer - from +30 to $+32{ }^{\circ} \mathrm{C}$, except for the lower reaches of the river. The Amu Darya, where the average annual temperature is from +11 to $+14{ }^{\circ} \mathrm{C}$, and the winter temperature is from -4 to $-6{ }^{\circ} \mathrm{C}$. The sum of positive temperatures per year reaches 5000-5500, and in the extreme south and in the desert - 6000. The intermountain valleys are characterized by a large amount of precipitation - 450-700 $\mathrm{mm}$ and a warm climate. The average annual temperature is $+16+$ $18{ }^{\circ} \mathrm{C}$, and the summer temperature is $+32{ }^{\circ} \mathrm{C}$. Although the Amu Darya valley has been inhabited since time immemorial, the complexity of natural conditions - desert, continental climate, did not allow the development of a high population density, and by 1960 less than 8 million people lived in the basin. According to the information portal CAWater-Info, as of January 1, 2017, 25,095 thousand people live in the basin, including Afghanistan. Average annual population growth rates in the CIS countries are 1.2-1.5\%; in Afghanistan, it is twice as high.

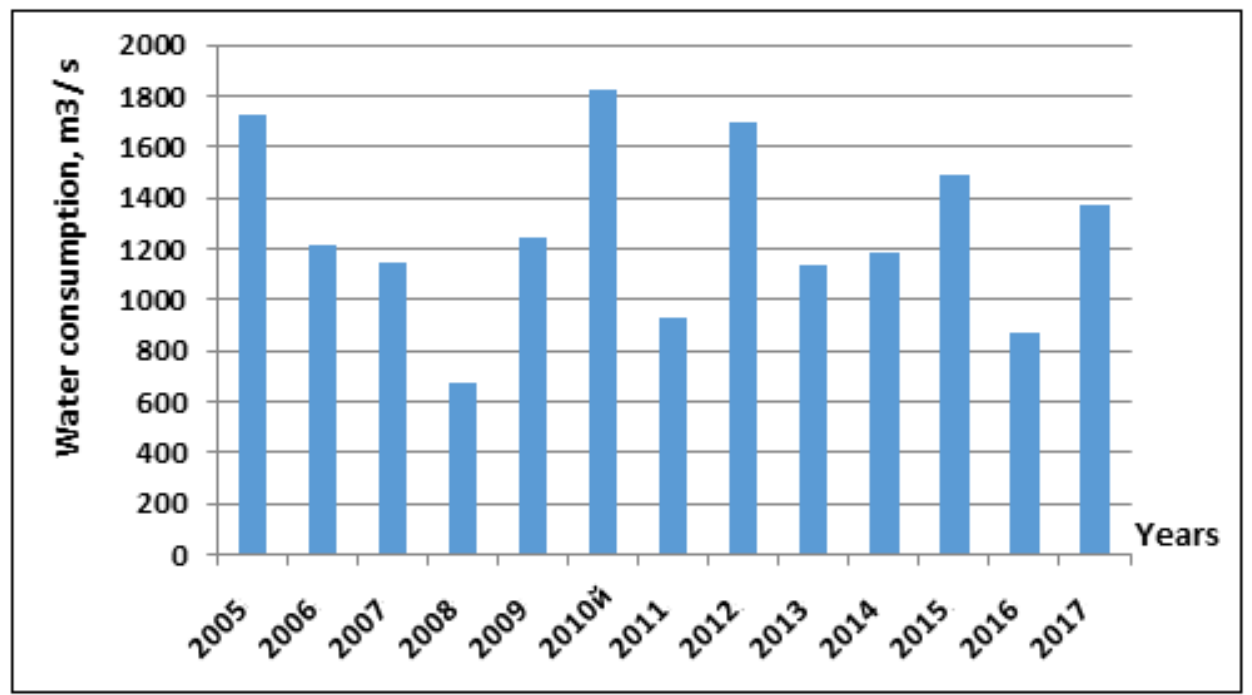

Fig. 1. Change in average annual water discharge in the middle reaches of the Amu Darya river 
The highest average annual water discharge was observed in the following years: in $2005-1722 \mathrm{~m}^{3} / \mathrm{s}$; in $2010-1822 \mathrm{~m}^{3} / \mathrm{s}$; in $2012-1691 \mathrm{~m}^{3} / \mathrm{s}$. From 1980 to 2003 , the lowest average annual water discharge was observed: in $2008-671 \mathrm{~m}^{3} / \mathrm{s}$; in $2011-929 \mathrm{~m}^{3} / \mathrm{s}$; in $2016-866 \mathrm{~m}^{3} / \mathrm{s}$.

Changes in flow rates and water levels for the conditions of the middle course of the Amu Darya river were studied based on water flow measurements carried out at several sections. In addition to them, materials of field observations of the operating service of the Uzhydromet canal were also used.

The change in the mean monthly water levels in the average course of the Amu Darya from 2001 to 2017 is shown in Graph 2. As can be seen from Graph 2, for the period under consideration, the highest average monthly water levels on the Amu Darya River in the city of Chardzhou were observed in 2010 and 2017, (189.37 m), and the lowest levels were observed in 2008 and 2011.

The change in the mean monthly water levels in the average course of the Amu Darya from 2001 to 2017 is shown in Graph 2. As can be seen from Graph 2, for the period under consideration, the highest average monthly water levels on the Amu Darya River in the city of Chardzhou were observed in 2010 and 2017, (189.37 m), and the lowest levels were observed in 2008 and 2011.

To provide agriculture with the required volume of water, the design and construction of many hydraulic structures and the reconstruction of existing facilities, taking into account climatic factors, is required.

To do this, it was necessary to study the climate model CMIP5 "Combined model by intercomparison project" phase five, which facilitates a standard set of simulation models. This data on climate change was obtained through the new Earth System Grid portal - the Center for Supporting Technologies. "The Coordinated Regional Climate Mitigation Experiment [5] provides global coordination of regional climate scaling for improved adaptation to regional climate change and impact assessment." Reduced CMIP5 data were obtained for the CORDEX region of South Asia, designated the WAS44 region. This dataset was carried out to generate a set of projected local climate data. Phase 5 of the Coupled Model Intercomparison Project (CMIP5) [6] is a collaborative effort to improve knowledge of climate change. The resulting climate dataset is then calibrated according to historical datasets, and its biases have been corrected using the existing equations for the Amu Darya river basin. Climate datasets provide data in the form of grid points at $44 \mathrm{~km}$ by $44 \mathrm{~km}$. The image below shows the resulting climate datasets and their geographic locations.

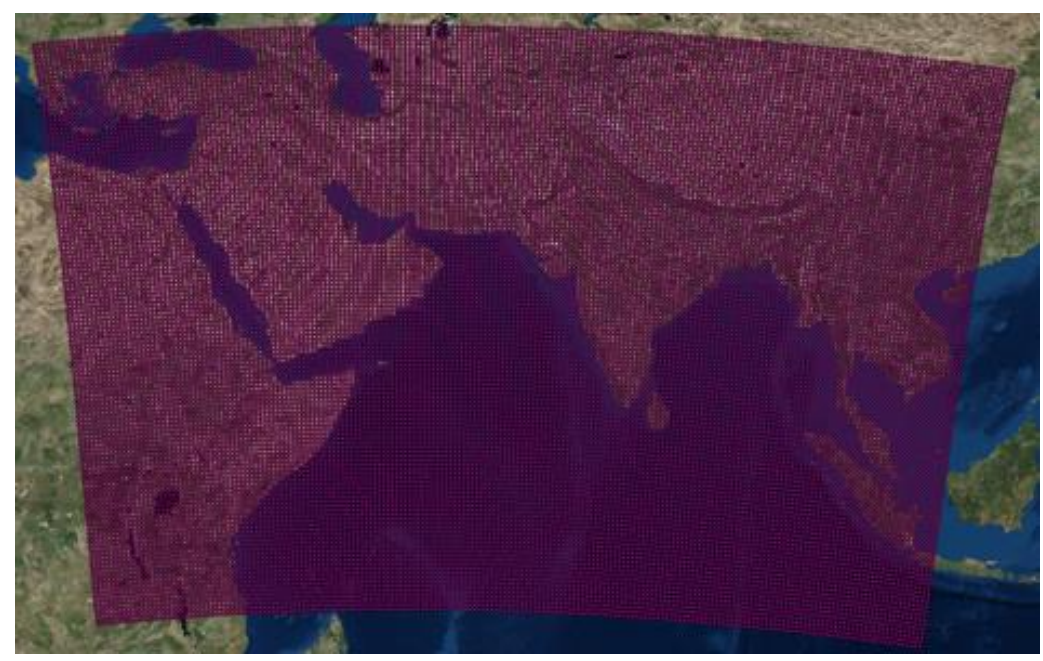


Fig. 2. Climate gridded datasets for South Asia, including southern Central Asia

Each grid point provides climate parameters, where these parameters are then adjusted according to the local available historical weather data. For the entire Amu Darya basin, 136 grid points are located, which are shown in the image below. These grid points provide parameters for temperature, wind speed, and precipitation. But it is not recommended to use all the grid data as we think it is ready to use. Before using the data, it is necessary to obtain observational data for the climate and adjust the GCM data following the historical observational data [7].
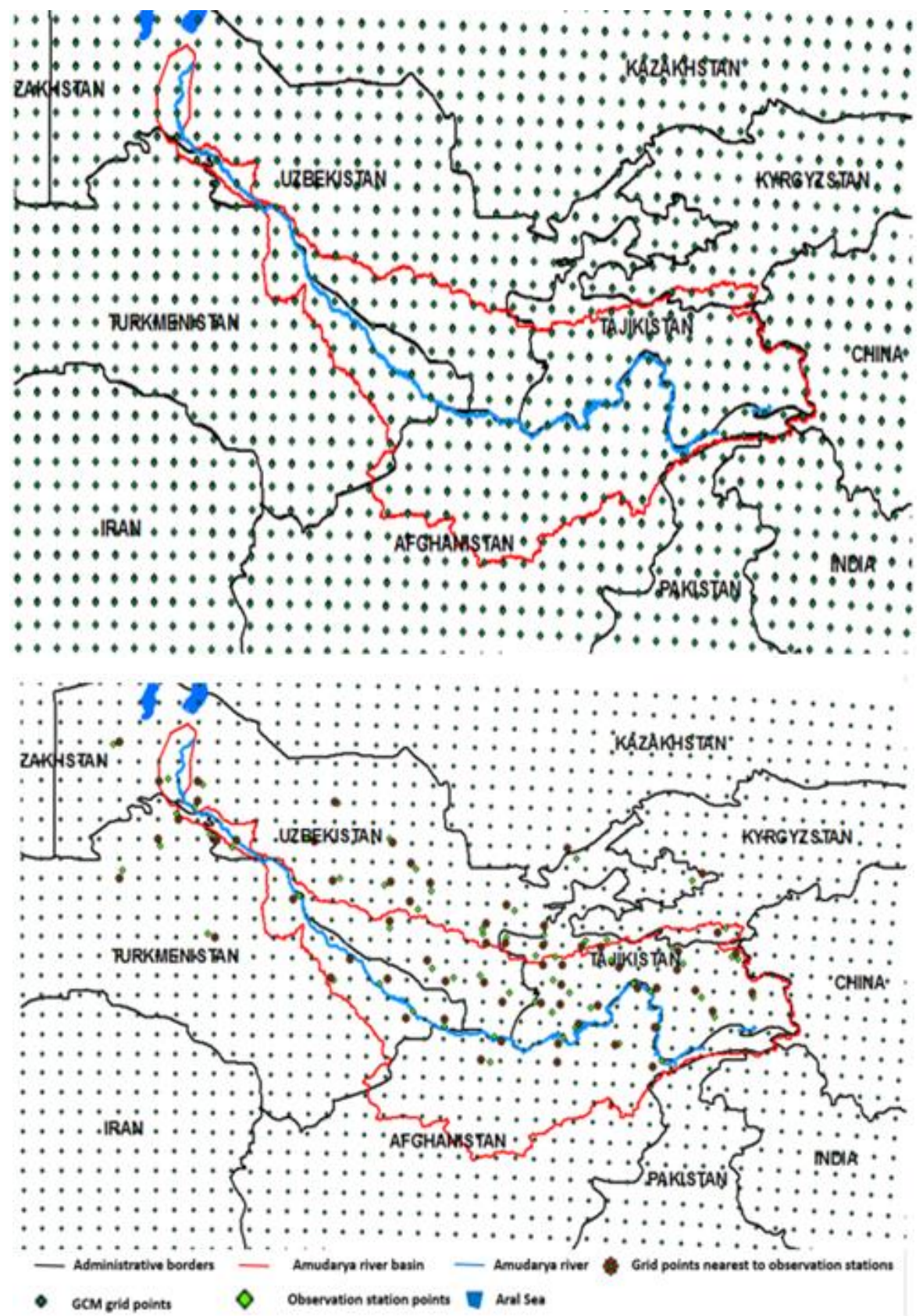
Fig. 3. GCM Grid Points in the Study Area

Many GCM datasets are used all over the world today. Their modeling of hydrological climate change is widely used in impact studies, but their application is difficult due to the possible risk of significant errors. Therefore, several bias correction methods and approaches have been developed [8] to correct the biases of the GCM datasets following observational data. Therefore, for the stage of offset correction, it is necessary to have and obtain the parameters of the observed climate. For this study, 62 sets of climate station data were obtained and used to calibrate and correct the bias. The image below shows both GCM grid points and observation stations. Climate models also include a time element called a time step [9].

The offset correction approach recommends using observation station data and GCM grid data that are located near the observation points. A total of 62 points from both observation and GCM were used to correct the bias. The offset correction formula used in this study is shown below.

Offset Correction Factor:

Bias Correction Factor $(B C)=M M C V_{\text {obs }} \%$ or $-M M C V_{\text {his }}$ (Where $M M C V-$ Mean monthly climate variable)

Corrected Climate Variable Present $\left(C V_{c(\text { his })}\right)=C V_{\text {his }} *$ or $+B C$

Corrected Climate Variable Future $\left(C V_{c(f u)}\right)=C V_{f u} *$ or $+B C$

The above equation serves to correct errors in the GCM dataset. According to scenarios, only selected data close to observations will be corrected [10] and used for future forecast. An increase in the use of water resources and a simultaneous increase in requirements for the quality of the withdrawn water pose several problems, the solution of which can affect the efficiency of the facilities and environmental safety [11].

\section{Results and Discussion}

Why bias correction is needed? Bias correction is not magic and uses mathematical or statistical techniques to effectively improve the mean and variance of climatic parameters.
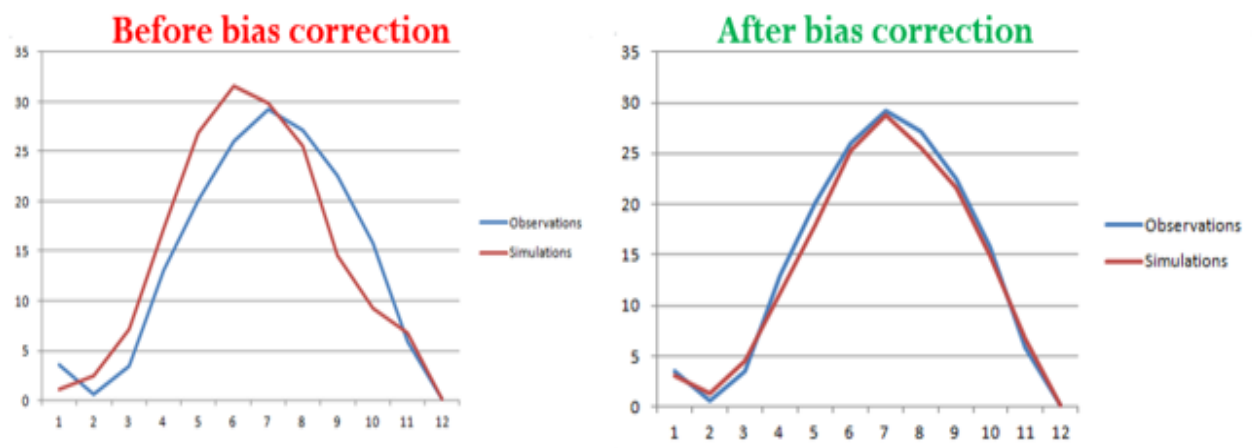

Fig. 5. Temperature plot with offset correction

The bias factor for adjusting the GCM data is used for future predicted data and predicted future climate variability using various scenarios available. The forecasts of changes in the average maximum, average, average, and minimum average temperatures for the future are presented below. 


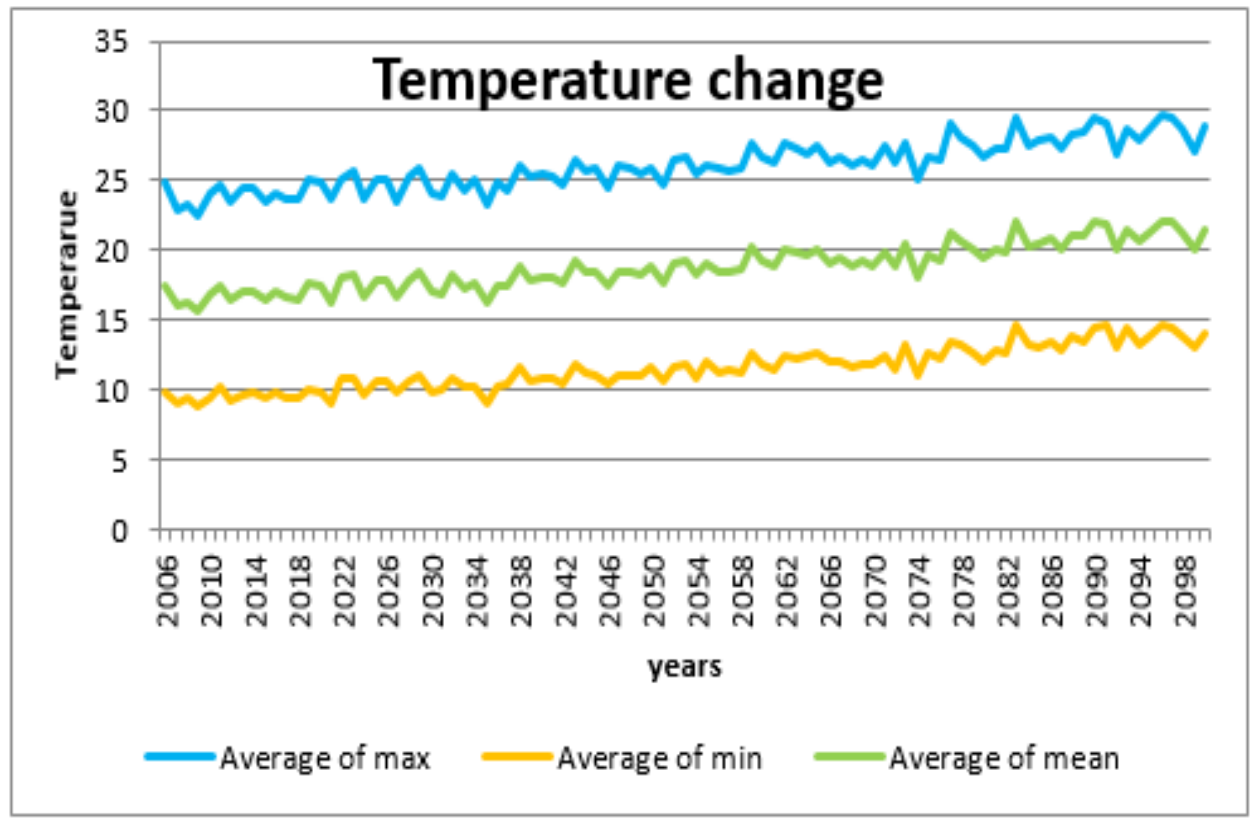

Fig. 6. Future changes in temperature in the Amu Darya basin

\section{Conclusions}

Based on the results of observations and discussions, the following conclusions were made:

1. We can observe that in the future, temperatures will increase from year to year, which means that the number of dry days may increase, and the demand for water resources will certainly increase. This is because as temperatures rise, each sector, such as agriculture, industry, or livestock, needs more water to maintain life and sustainability.

2. An analysis of the results of field research shows that taking into account climatic factors on the operating regime of hydraulic structures in the Amu Darya basin, developing new programs for forecasting climate change using are necessary tasks.

3. To provide agriculture with the required volume of water, the design and construction of many hydraulic structures and the reconstruction of existing facilities, taking into account climatic factors, is required.

4. Higher temperatures also increase drought, reduce summer precipitation, and increase evaporation, reducing the availability of surface water. Therefore, these changes encourage us to more actively consider climate change in the region, take the necessary measurements to solve the problems in the region, and focus on improving water resources management and distribution in both the middle and lower reaches. 


\section{References}

1. Marcus Malsy, Tim aus der Beek, Stephanie Eisner and Martina Floerke, Climate change impacts on Central Asian water resources. Advances in Geosciences, 32, pp. 77-83, (2012)

2. Hagg W., Mayer C., Lambrecht A., Kriegel D., and Azizov E. Glacier changes in the Big Naryn basin, Central Tian Shan,Global Planet. Change, 110, pp. 40-50, (2013)

3. Amudarya river basin, Amudarya river basin network webside http://amudaryabasin.net/content/amu-darya-river-basin.

4. Bazarov D., Markova I., Norkulov B., Isabaev K., Sapaeva M. Operational efficiency of water damless intake. IOP Conf. Ser. Mater. Sci. Eng. 869(7), 072051, (2020)

5. Sokolov, V. Future of irrigation in Central Asia. IWMI-FAO Workshop on trends and transitions in Asian irrigation. What are the prospects for the future, 19-21 January, Bangkok, (2009)

6. Bazarov D., Vatin N., Obidov B., and Vokhidov O. Hydrodynamic effects of the flow on the slab of the stand in the presence of cavitation. IOP Conf. Ser. Mater. Sci. Eng. 1030, 012110 (2021)

7. Obidov B., Vokhidov O., Tadjieva D., Kurbanova, U., Isakov A. Hydrodynamic effects on the flow elements of the downstream devices in the presence of cavitation. IOP Conf. Ser. Mater. Sci. Eng. 1030, 012114 (2021)

8. Cordex Global Climate Model dataset archive http://www.cordex.org/

9. Taylor K.E., Stouffer R.J., and Meehl G.A., "An overview of CMIP5 and the experiment design," Bulletin of the American Meteorological Society, 93, № 4, pp. 485-498, (2012)

10. Krutov A., Choriev R., Norkulov B., Mavlyanova D. and Shomurodov A. Mathematical modelling of bottom deformations in the kinematic wave approximation. IOP Conf. Ser. Mater. Sci. Eng. 1030, 012147 (2021)

11. Aleinov I., and Schmidt G.A. Water isotopes in the GISS Model land surface scheme. Global Planet. Change 51, pp. 108-120, doi:10.1016/j.gloplacha.2005.12.010. (2006)

12. Claudia T., Jan S. Bias correction of regional climate model simulations for hydrological climate-change impact studies, Review and evaluation of different methods, (2012)

13. Krutov A., Norkulov B., Uljaev F., and Jamalov F. Results of a numerical study of currents in the vicinity of a damless water intake. IOP Conf. Ser. Mater. Sci. Eng. 1030, 012121 (2021)

14. Wilby R.L. and Dawson C.W. The Statistical Down Scaling Model: insights from one decade of application, (2013)

15. Bazarov D. and Vokhidov O. Extinguishing Excess Flow Energy in Spillway Structures. In book: Proceedings of EECE 2020, LNCE 150, pp. 535-545, (2021) DOI: 10.1007/978-3-030-72404-7_52

16. Cai X.M., and Rosegrant M. $\bar{W}$. Sustainability Analysis for Irrigation Water Management in the Aral Sea Region, Agricultural Systems 3, pp. 1043-1066, (2003)

17. Bazarov D., Mavlyanova D.A. Numerical studies of long-wave processes in the reaches of hydrosystems and reservoirs

18. Bazarov D., Markova I., Sultanov S. and Kattakulov F. Dynamics of the hydraulic and alluvial regime of the lower reaches of the Amudarya after the commissioning of the Takhiatash and Tuyamuyun hydrosystems, IOP Conf. Ser. Mater. Sci. Eng. 1030, 012110 (2021)

19. Krutov A., Norkulov B., Nurmatov P., Mirzaev M. Applicability of zero-dimensional equations to forecast nonconservative components concentration in water bodies. IOP Conf. Ser. Mater. Sci. Eng. 883(1), 012028 (2020) 
20. Matyakubov B., Begmatov I., Raimova I., and Teplova G. Factors for the efficient use of water distribution facilities. IOP Conf. Ser. Mater. Sci. Eng. 883, 012025 (2020).

21. Uralov B., Rakhmatov N., Khidirov S., Uljaev F., Raimova I. Hydraulic modes of damless water intake. IOP Conf. Ser. Mater. Sci. Eng. 1030(1), 012123 (2021)

22. Bazarov D., Markova I., Raimova I., Sultanov Sh. Water flow motion in the vehicle of main channels. IOP Conf. Ser. Mater. Sci. Eng. 883, 012025 (2020)

23. Krutov A., Norkulov B., Artikbekova F., Nurmatov P. Optimal location of an intake at a reservoir prone to salt diffusion. IOP Conf. Ser. Mater. Sci. Eng. 869(7), 072020, (2020) 